\title{
Prognostic meaning of tissue inhibitors of matrix metalloproteinases TIMP-1 and TIMP-2 in patients with colorectal cancer
}

\author{
Elena Kostova $^{1 *}$, Slavica Shubeska Stratrova ${ }^{2}$ \\ ${ }^{I}$ Department of Preclinical and Clinical Pharmacology and Toxicology, Medical Faculty, \\ Ss. Cyril and Methodius University, 50 Divizija 6,1000 Skopje, Republic of North Macedonia \\ ${ }^{2}$ University Clinic of Endocrinology, Diabetes and Metabolic disorders, \\ Medical Faculty, Ss. Cyril and Methodius University, Mother Theresa 17, 1000 Skopje, \\ Republic of North Macedonia
}

Received: November 2019; Accepted: January 2020

\begin{abstract}
The aim of this study was to analyze TIMP-1 and TIMP-2 serum levels in patients with colorectal cancer (CRC) and to correlate the results with the pathological stage of the disease and outcome in order to evaluate the role of TIMP-1 and TIMP-2 serum levels as prognostic markers.

The investigation has been made on 82 patients with operable CRC without distant metastases, who had undergone blood tests in order to determine the TIMP-1 and TIMP-2 serum levels in the following points of time: preoperatively, as well as 3, 6, 9 and 12 months postoperatively.

Significant differences were found between serum levels of TIMP-1 and TIMP-2 obtained preoperatively and postoperatively, as well as significant association of serum TIMP-1 levels obtained preoperatively in CRC patients in stage I and III, in the $3^{\text {th }}$ and in the $6^{\text {th }}$ month $(p<0.001)$ postoperatively as defined points of time with the outcome of CRC patients. Serum TIMP-2 levels obtained preoperatively was significantly associated with the outcome of the CRC patients. Analysis of the obtained TIMP-1 and TIMP-2 serum levels in CRC patients showed statistically significant differences with: disease progression, occurrence of liver metastasis, prior to and post chemotherapy treatment.

The results derived a conclusion that the serum levels of TIMP-1 and TIMP-2 could be indicators for occurrence and progression of $\mathrm{CRC}$, as well as valuable and useful markers for following the effects of chemotherapy treatment.
\end{abstract}

Keywords: colorectal cancer, TIMP-1, TIMP-2, prognosis

\section{Introduction}

Colorectal cancer (CRC) prognosis predominantly depends on the disease stage, but new prognostic factors are being investigated in order to determine disease progression and outcome in patients as well as postsurgical pharmacology treatment (Ferlay et al., 2010).
The correct staging of each CRC patient is crucial in order to plan an optimal treatment regimen. It is widely recognised that prognostic information based on clinical and histopathological investigation may be insufficient, although tumour stage and lymph node involvement are the main prognostic tools in evaluating cancer specific survival. It is questionable to expose a large number of patients to adjuvant treatment with considerable side

\footnotetext{
*eli_kos_pet@yahoo.com
} 
effects without indications that they will benefit from such treatment. Finding prognostic markers to better identify patients with higher risk for poor survival would be valuable in order to customise pre- and post-operative treatment as well as enabling closer follow-up for these patients (Graziano and Cascinu, 2003; Zlobecand Lugli, 2008).

Matrix metalloproteinases (MMPs) are a family of extracellular structurally related zinc-dependent endoproteases capable of degradingall the extracellular matrix (ECM) components. MMPs play an important role in the physiologic degradation of ECM and are associated with tumorprogression including invasion, migration, angiogenesisand metastasis (Graziano and Cascinu, 2003).

Tissue inhibitors of matrix metalloproteinases (TIMPs) are a family of natural MMPs inhibitors that appear to affect many aspects of cancer biology. TIMPs role is not restricted only to MMPs inhibition but can modulate many cellular processes as cell growth, invasion, migration, metastasis, and angiogenesis and can be both anti- and protumorogenic (Makitalo, 2010; Visse and Nagase, 2003). TIMPs have similar structure in about 30 to $40 \%$ and inhibit MMPs proteolytic activity building 1:1 noncovalent stoichiometric complexes. Inhibiting MMPs TIMPs have a role of remodeling of extracellular matrix (ECM). There are 4 types of TIMPs: 1, 2, 3 and 4. TIMP$1,-2$, and -4 are present in soluble form and TIMP-3 is present in ECM (Leco et al.,1994).

TIMP-1 (tissue inhibitor of metalloproteinases-1, human collagenase inhibitor, fibroblast collagenase inhibitor, EPA-erythroid potentiating activity) was first detected in the culture of fibroblasts and represents 28.5 KD secretory protein whose mRNA is found in macrophages, keratinocytes, endothelial cells andfibroblasts (DeClerck et al., 1992; Welgus et al., 1981).

TIMP-1 inhibits activity of MMP-7, -14, -16, -19 and -24 , but also has a role in the promotion and stimulation of cell growth by inhibiting apoptosis (Amour et al., 1998; Nagase et al., 2006). Elevated TIMP-1 levels in blood circulation was expected to be a useful prognostic indicator for cancer patients due to inhibitory effect on MMPs, but in a number of published studies claim otherwise because TIMP-1 inhibits the apoptosis.

Several previous studies of TIMPs role in various cancer diseases have shown contradictory results, and some of them have shown that serum levels of TIMPs may play important role as an indicator of occurring of CRC and its progression (Albini, 1991; DeClerck et al., 1992; Giaginis et al., 2009; Oberg et al., 2000).

In the present study we have measured TIMP-1 and TIMP-2 serum levels in patients with CRC and we correlated the results with the pathological stage of the disease and outcome in order to evaluate the role of TIMP-1 and TIMP-2 serum levels as a prognostic markers and markers that may indicate the changes in cancer disease progression.

\section{Materials and methods}

The study included a total of 82 previously untreated CRC patients, 30 females and 52 males (age range from 43 to 75 years, averaged 67.85) with operable CRC, without detectable distant metastases, who respected the medical instructions and were available for follow-up. All the patients underwent surgical resection of the primary neoplasm at the University Clinic for Abdominal Surgery in Skopje in the period of 2 years.

Blood samples from all the patients were drawn before surgical treatment, as well as 3, 6, 9, and 12 months postoperatively, in order to examine the TIMP-1 and TIMP-2 serum levels. None of the CRC patients had received chemotherapy before blood sample collection. To standardize clotting conditions, all serum samples were separated within $1 \mathrm{~h}$ after blood collection, aliquoted and stored at $-80{ }^{\circ} \mathrm{C}$ until assayed.

Serum levels of TIMP-1 and TIMP-2 were determined using a quantitative solid phase sandwich enzyme-linked immunosorbent assay (ELISA) (R\&D Systems, USA) according to the manufacturer's instructions. High concentrations of TIMP-1 and TIMP-2 were diluted with calibrator, to produce samples with values within the dynamic range of the assay.

The histopathological analysis of surgically removed operative material was made at the Institute of Pathology at the Faculty of Medicine, Skopje, where the pathological stage was defined for every patient according to the International Union Against Cancer (UICC-pTNM) and American Joint Committee on Cancer (AJCC), 2010.

Forty-three patients with Stage II B and III (A, B, C) received adjuvant chemotherapy, postoperatively at the Institute for Radiotherapy and Oncology in Skopje.

Correlations were made between the MMPs serum levels and the pathological parameters.

\section{Statistical analysis}

Descriptive statistics data are given according to normality of the distribution. Normality of the distribution was determined by Kolmogorov-Smirnov's test. Analysis of variance with Kruskall-Wallis test was used in the analysis of different sample types. In the case of significant results, the analyses were continued by pairing the variables and analyzing them with Mann-Whitney's U-test. Fisher's exact probability test and Pearson's ChiSquare test (r) were used for testing the association (linearity of the correlation of serum concentrations) between TIMPs and major prognostic variables in CRC, such as grade and stage. P-values less than $0.05(p<0.05)$ were considered as statistically significant. 


\section{Results}

There have been $17(20.73 \%)$ patients in stage I, 40 $(48.78 \%)$ patients in stage II and $25(30.48 \%)$ patients in stage III of the CRC. Lymph node metastases were substantiated in $25(30.48 \%)$ patients and were not find in $57(69.51 \%)$ patients with different pT category.

The majority of patients were with pT3N0M0 $(26.82 \%)$, i.e. patients in stage II A of the disease, and the smallest number of patients were with pT4aN1M0 $(4.87 \%)$, i.e. patients in stage III B of the CRC.

Table 1. Staging of CRC patients according to AJCC

\begin{tabular}{cccc}
\hline \hline Stage & pTNM & $\begin{array}{c}\text { N } \\
(82)\end{array}$ & $\begin{array}{c}\text { Percent } \\
(\%)\end{array}$ \\
\hline I & pT1N0 M0 & 8 & 9.75 \\
I & pT2 N0 M0 & 9 & 10.97 \\
II A & pT3 N0 M0 & 22 & 26.82 \\
II B & pT4a N0 M0 & 18 & 21.95 \\
III B & pT3 N1b M0 & 7 & 8.53 \\
III B & pT3 N2a M0 & 9 & 10.97 \\
III B & pT4a N1b M0 & 4 & 4.87 \\
III C & pT4a N2b M0 & 5 & 6.09 \\
\hline
\end{tabular}

The mean TIMP-1 levels in patients in all stages of the disease decreased after tumor resection, whereas the mean serum values in stage III demonstrated most intensive changes, unlike the mean serum values in CRC patients in stage I and II which showed mild changes. All three groups of followed patients showed decreasing values postoperatively, where the decline was most evident in $3^{\text {th }}$ month postoperatively in all CRC patients at all determined stages.

Mean serum levels of TIMP-1 in CRC patients in stage II remained approximately at the same level in further defined points of time, with a slightly increase in $9^{\text {th }}$ and $12^{\text {th }}$ month postoperatively.

Mean TIMP-1 serum levels of CRC patients in stage I showed approximately the same movement, while the curve mean TIMP-1 serum levels of CRC patients in stage III showed a plateau values from $3^{\text {th }}$ to $6^{\text {th }}$ month postoperatively, then abruptly increases at $9^{\text {th }}$ month and again achieves plateau up to 12 months postoperatively.

Most evident decline in mean serum levels of CRC patients was observed at $6^{\text {th }}$ month postoperatively in all determined stages, and the most pronounced increase in mean serum levels was observed in CRC patients in stage III, especially in the defined points from $6^{\text {th }}$ to $9^{\text {th }}$ months postoperatively.

The explanation of this condition would be identical as in previously displayed results of the other investigated parameters, i.e. due to the change of condition of the disease in patients most of the stage III, in which is shown the largest percentage of lethal outcomes.

Table 2. Mean serum TIMPs (ng/mL) values in terms of stages and defined points of time

\begin{tabular}{ccccccc}
\hline \hline $\begin{array}{c}\text { Defined points } \\
\text { in time }\end{array}$ & $\begin{array}{c}\text { TIMP-1 Stage } \\
\text { I }\end{array}$ & $\begin{array}{c}\text { TIMP-1 Stage } \\
\text { II }\end{array}$ & $\begin{array}{c}\text { TIMP-1 Stage } \\
\text { III }\end{array}$ & $\begin{array}{c}\text { TIMP-2 Stage } \\
\text { I }\end{array}$ & $\begin{array}{c}\text { TIMP-2 Stage } \\
\text { II }\end{array}$ & $\begin{array}{c}\text { TIMP-2 Stage } \\
\text { III }\end{array}$ \\
\hline Preoperat. & 176.2 & 228.66 & 348.62 & 150.01 & 222.56 & 333.29 \\
SD & 46.87 & 66.11 & 102.97 & 31.35 & 65.11 & 97.24 \\
Max & 277.5 & 362.5 & 633 & 220.5 & 329.4 & 586 \\
Min & 115.4 & 89.5 & 175 & 102 & 65.5 & 162 \\
& & & & & & \\
3 months postop. & 157.74 & 215.05 & 257.98 & 240.91 & 201.49 & 245.99 \\
SD & 54.82 & 215.05 & 50.98 & 48.3 & 65.53 & 50.49 \\
Max & 355 & 64.86 & 372.4 & 324.3 & 313.5 & 334.3 \\
Min & 137.5 & 50.6 & 176 & 136.4 & 58.5 & 126.7 \\
& & & & & & \\
6 months postop. & 156.16 & 215.51 & 257.74 & 121.78 & 194.69 & 240.91 \\
SD & 34.3 & 64.19 & 54.82 & 28.83 & 64.86 & 48.3 \\
Max & 209 & 345.5 & 355 & 170.3 & 307.4 & 324.3 \\
Min & 95 & 55.5 & 137.5 & 79.8 & 29.2 & 136.4 \\
& & & & & & \\
months postop. & 161.11 & 216.43 & 334.18 & 132.05 & 201.27 & 310.5 \\
SD & 40.45 & 59.54 & 109.13 & 30.61 & 62.44 & 104.8 \\
Max & 225 & 360 & 603 & 199 & 305.6 & 561 \\
Min & 82 & 100.5 & 150.2 & 80.8 & 70.4 & 135.6 \\
& & & & & & \\
12 months postop. & 169.23 & 219.82 & 336.69 & 138.17 & 203.36 & 321.45 \\
SD & 44.88 & 60.05 & 102.09 & 28.82 & 58.57 & 96.02 \\
Max & 262 & 155.2 & 610 & 205 & 300.4 & 550.5 \\
Min & 110 & 110.5 & 165 & 92.5 & 90.7 & 147 \\
\hline
\end{tabular}

Макед. фарм. билт., 66 (1) 25 - 32 (2020) 


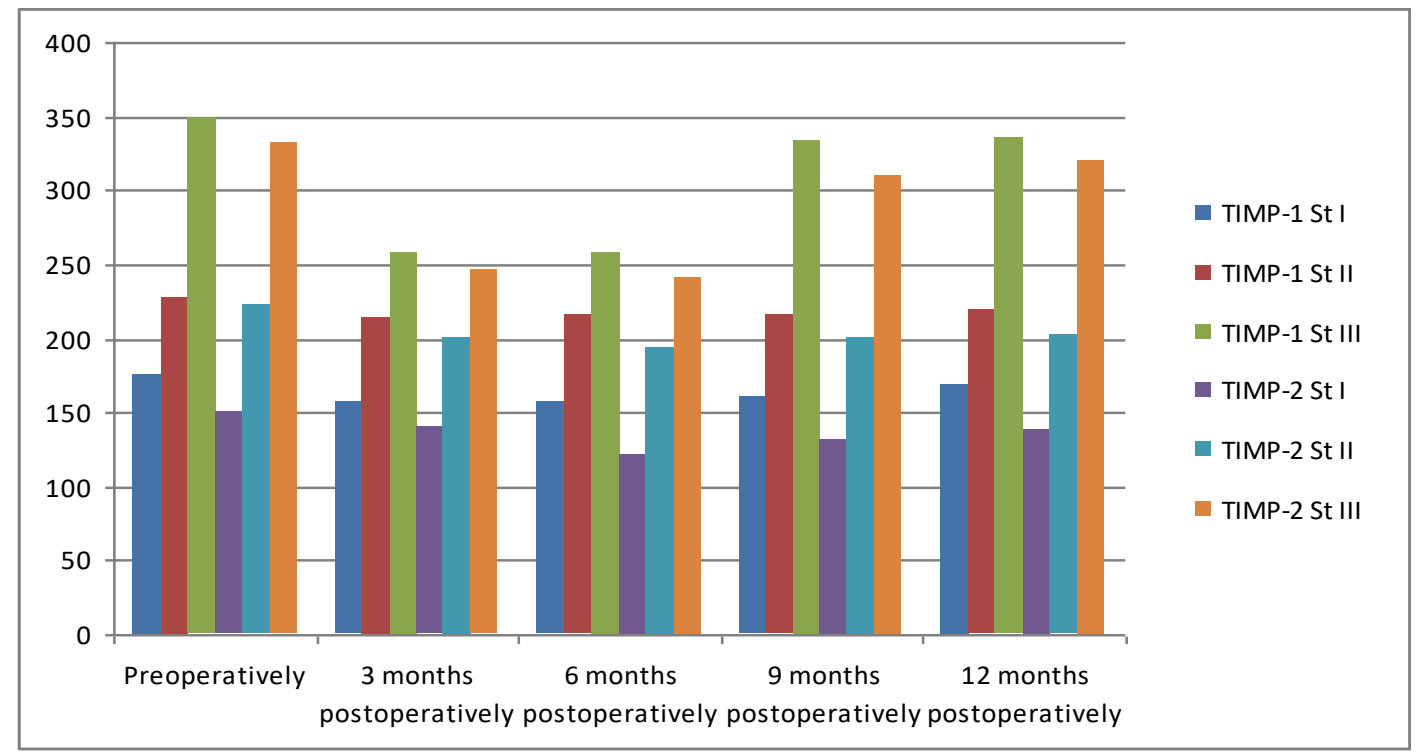

Fig. 1. Mean serum TIMP-1 (ng/mL) and TIMP-2 (ng/mL) levels in terms of stage and time.

In Table 3 are presented significant associations in TIMP-1 and TIMP-2 and outcome of the CRC patients, where it is shown that serum levels of TIMP-1 and TIMP2 preoperatively, as well as the TIMP-2 serum levels in $3^{\text {th }}$ and $6^{\text {th }}$ month postoperatively, are in a significant correlation with the outcome of the CRC patients.

Table 3. Significant correlations of serum levels of TIMPs (ng/mL) and CRC patients' outcome

\begin{tabular}{ccc}
\hline \hline Parameter & $p$ & $\mathrm{R}$ \\
\hline Stage & $<0.001$ & 0.635 \\
$\mathrm{pT}$ & $<0.005$ & 0.331 \\
$\mathrm{pN}$ & $<0.005$ & 0.618 \\
TIMP-1 preoperatively & $<0.001$ & 4.0279 \\
TIMP-1; 3 months postop. & $<0.001$ & 4.0595 \\
TIMP-1; 6 months postop. & $<0.001$ & 4.6553 \\
TIMP-1; 9 months postop. & $\mathrm{NS}$ & $/$ \\
TIMP-1; 12 months postop. & $\mathrm{NS}$ & $/$ \\
TIMP-2 preoperatively & $<0.001$ & 4.5372 \\
TIMP-2; 3 months postop. & $\mathrm{NS}$ & $/$ \\
TIMP-2; 6 months postop. & $\mathrm{NS}$ & 5.1124 \\
TIMP-2; 9 months postop. & $\mathrm{NS}$ & $/$ \\
TIMP-2; 12 months postop. & $\mathrm{NS}$ & $/$ \\
\hline
\end{tabular}

NS - not significan
There were significant differences between the mean serum levels of TIMP-1 before tumor resection and $3^{\text {th }}$ and $6^{\text {th }}$ month $(p<0.001)$ postoperatively in CRC patients in stage I and III, between $3^{\text {th }}$ and $6^{\text {th }}$ month and $9^{\text {th }}$ and $12^{\text {th }}$ month postoperatively in CRC patients in stage III ( $p<0.001$ among all) and between preoperative and postoperative levels during defined control points of time in CRC patients in stage II.

Regarding mean serum levels of TIMP-2 obtained prior to surgical intervention and $6^{\text {th }}$ month in all CRC patients stages postoperatively we found statistically significant differences between mentioned features $(p<0.001)$, as well as between $3^{\text {th }}$ and $6^{\text {th }}$ month and $9^{\text {th }}$ and $12^{\text {th }}$ month postoperatively in CRC patients in stage III ( $p<0.001$ among all).

The CRC patients with different stages who received and who didn't receive chemotherapy treatment, and their outcome are shown in Table 4.

In twenty patients that were particularly monitored to the appearance of liver metastasis and subsequently were administered first-line chemotherapy treatment (in patients with stage I and II A) and additional second-line chemotherapy treatment (in patients with stage II B and III).

The liver metastasis was substantiated by imaging techniques and liver biopsy with histological confirmation with the following distribution: in 2 patients of stage I, 3 patients of stage II A, 4 patients of stage II B, 8 patients of stage III B and in 3 patients of Stage III C.

In these patients' blood samples were drown additionally for quantifying of TIMPs serum levels prior to and post chemotherapy treatment in order to determine 
Table 4. Distribution of the CRC patients according received and non-received chemotherapy treatment and outcome

\begin{tabular}{ccccccc}
\hline $\begin{array}{c}\text { Stadium } \\
\mathrm{n}=82\end{array}$ & $\begin{array}{c}\text { With } \\
\text { chemo-therapy }\end{array}$ & $\%$ & $\begin{array}{c}\text { Without } \\
\text { chemo-therapy }\end{array}$ & $\%$ & $\begin{array}{c}\text { Poor } \\
\text { outcome }\end{array}$ & $\%$ \\
\hline Stadium I & $/$ & $/$ & 17 & 20.73 & 6 & 7.31 \\
Stadium IIA & $/$ & $/$ & 22 & 26.82 & 8 & 9.75 \\
Stadium IIB & 18 & 21.95 & $/$ & $/$ & 11 & 13.41 \\
Stadium IIIB & 20 & 24.39 & $/$ & $/$ & 15 & 18.29 \\
Stadium IIIC & 5 & 6.09 & $/$ & $/$ & 3 & 3.65 \\
Total & 43 & 52.43 & 39 & 47.56 & 43 & 52.43 \\
\hline
\end{tabular}

variability of serum levels for their role as markers, which could indicate a change in the condition of the disease in CRC patients, that indicate possible progression and occurrence of metastases.

The mean serum levels of TIMP-1 and TIMP-2 in CRC patients obtained prior to chemotherapy treatment reached approximately the levels of the mean values of the group of CRC patients in stage IIIC in $12^{\text {th }}$ month separately, while the mean serum levels abruptly decreased $(p<0.001)$ post chemotherapy treatment, i.e. similar values were obtained after resection of the primary neoplasm.

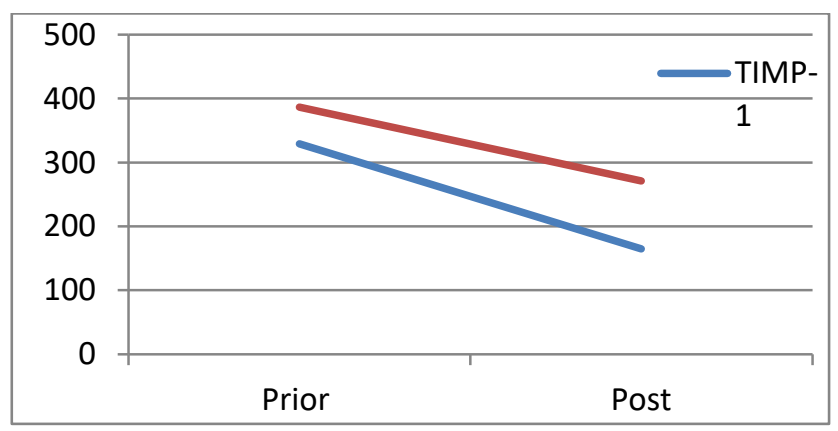

Fig. 2. Mean serum TIMP-1 (ng/mL) and TIMP-2 (ng/mL) levels prior to and postchemotherapy treatment.

\section{Discussion}

TIMPs are also linked with a wide variety of other functions of cell growth and survival,andat least some of these functions seem to be independent of MMP inhibition.TIMP-1 and TIMP-2 were first identified as proteins potentiating the epo-effect on proliferationand differentiation of erythroid progenitor cell (Gasson et al., 1985).

Additionally, the cell-growth promoting effects of
TIMP-1 and -2 have beenshown in various normal and malignant cell lines (Hayakawa et al., 1998; Yamashita et al., 1996). There is some evidence supporting the hypothesis that TIMPs' role as growth stimulatorsand MMP inhibitors is functionally as well as possibly structurally separated (Chesler et al., 1995).

The role of TIMPs in cancer is very complex, and acknowledging the fact that angiogenesis and ECM degradation are very crucial in tumor cell spreading and metastasis formation,it isobvious that TIMPs have a role of some importance in cancer. Previously the TIMPs' role as MMP inhibitors seemed most important, and there is clear evidence thatdownregulation of TIMP-1 and TIMP2 expression is associated with increased invasivenessof tumors, while overexpression leads to reduced tumor growth and metastasis formation in tumors of various origins (Chesler et al., 1995).

In meta-analysis for determining plasma and serum levels TIMP-1 as predictors of the outcome of CRC patients, Lee et al. (2011) reported that the elevated TIMP-1 values obtained in blood samples, as well as expression of TIMP-1, are associated with shorter survival time.

Contemporary researches have been made in order to determine the significance of the serum TIMP-1 levels in patients of pre-invasive to invasive $\mathrm{CRC}$, in order to diagnose the malignancies and to determine TIMP-1 influence on the disease's outcome (Pellegrini et al., 2000).

TIMP-2 (tissue inhibitor of metalloproteinases-2, CHIAMP-chondrocyte-derived inhibitor of angiogenesis and metalloproteinase activity, CSC-21K) could either promote the activity of MMP-2 through interaction with Mo1-MMPor to inhibit through direct action(StetlerStevenson, 2008). TIMP-2 can reduce proliferation of endothelial cells, fibroblasts and some tumor cell lines. In a mouse model, TIMP-2 could protect from CRC and reduce the growth of the existing metastasis (Baker et al., 1998; Brand et al., 2000; Stetler-Stevenson and Seo, 2005). 
Table 5. Mean serum levels of TIMP-1 and TIMP-2 in 20 patients prior to and post chemotherapy treatment

\begin{tabular}{lcc}
\hline \hline \multicolumn{1}{c}{ Time } & TIMP-1 $(\mathrm{ng} / \mathrm{mL})$ & TIMP-2 $(\mathrm{ng} / \mathrm{mL})$ \\
\hline Prior to chemotherapy & 329.03 & 386.19 \\
Postchemotherapy & 164.62 & 271.24 \\
\hline
\end{tabular}

Some researchers investigated TIMP-1 and -2 serum levels in $97 \mathrm{CRC}$ patients and discovered a significant correlation between elevated TIMP-1 serum levels and shorter survival time, which led them to the conclusion that the elevated TIMP-1 serum levels are an independent prognostic factor for survival in patients with CRC (Giaginis et al., 2009).

In the examination conducted by Oberg et al. (2000) on $158 \mathrm{CRC}$ patients was confirmed that the elevated serum TIMP-1 levels are significantly higher in patients with an advanced stage of the disease, and that the increased values of TIMP-2 were in correlation with worse prognosis.

$$
\text { / }
$$

\section{Conclusion}

In the present study significant differences were found between serum levels of TIMP-1 and TIMP-2 obtained preoperatively and postoperatively, as well as significant association of serum TIMP-1 levels obtained preoperatively, in the $3^{\text {th }}$ and in the $6^{\text {th }}$ month as defined points of time with the outcome of CRC patients. Serum TIMP-2 levels obtained preoperatively was significantly associated with the outcome of the CRC patients.

Analysis of the obtained TIMP-1 and TIMP-2 serum levels in CRC patients showed statistically significant differences with: disease progression, occurrence of liver metastasis, prior to and post chemotherapy treatment.

The results derived a conclusion that the serum levels of TIMP-1 and TIMP-2 could be indicators for occurrence and progression of CRC, as well as valuable and useful markers for following the effects of chemotherapy treatment.

\section{References}

Albini, A., Melchiori, A., Santi, L., Liotta, L.A., Brown, P.D., Stetler-Stevenson, W.G., 1991. Tumor cell invasion inhibited by TIMP-2. J. Nat. Cancer Inst. 83, 775-779. Available at: https://doi.org/10.1093/jnci/83.11.775.

Amour,A., Slocombe, P.M., Webster, A., Butler, M., Knight, C.G., Smith, B.J., Stephens, P.E., Shelley, C., Hutton, M., Knauper, V., Docherty, A.J., Murphy, G., 1998. TNFalpha converting enzyme (TACE) is inhibited by TIMP-3. FEBS Lett. 435, 39-44. Available at: https://doi.org/10.1016/S0014-5793(98)01031-X.

Baker A.H., Zaltsman A.B., George S.J., Newby A.C., 1998.
Divergent effects of tissue inhibitor of metalloproteinase$1,-2$, or -3 overexpression on rat vascular smooth muscle cell invasion, proliferation, and death in vitro. TIMP-3 promotes apoptosis. J. Clin. Invest. 101, 1478-1487. Available at: https://doi.org/10.1172/JCI1584.

Brand, K., Baker, A.H., Perez-Canto, A., Possling, A., Sacharjat, M., Geheeb, M., Arnold, W., 2000. Treatment of colorectal liver metastases by adenoviral transfer of tissue inhibitor of metalloproteinases- 2 into the liver tissue. Cancer Res. 60, 5723-5730.

Chesler, L., Golde, D.W., Bersch,N., Johnson, M.D., 1995. Metalloproteinase inhibition and erythroid potentiation are independent activities of tissue inhibitor of metalloproteinases-1. Blood 86, 4506-4515. Available at: https://doi.org/10.1182/blood.V86.12.4506.bloodjournal86 124506

DeClerck, Y.A., Perez, N., Shimada, H., Boone, T.C., Langley, K.E., Taylor, S.M., 1992. Inhibition of invasion and metastasis in cells transfected with an inhibitor of metalloproteinases. Cancer Res. 52, 701-708.

Ferlay, J., Parkin, D.M., Steliarova-Fiocher,E., 2010. Estimates of cancer incidence and mortality inEurope in 2008. Eur. J. Cancer 46, 765-781. Available at: https://doi.org/10.1016/j.ejca.2009.12.014.

Gasson, J.C., Golde, D.W., Kaufman, S.E., Westbrook, C.A., Hewick, R.M., Kaufman, R.J., Wong, G.G., Temple, P.A., Leary, A.C., Brown, E.L., 1985. Molecular characterization and expression of the gene encoding human erythroid-potentiating activity. Nature 315, 768771. Available at: https://doi.org/10.1038/315768a0.

Giaginis, C., Nikiteas, N., Margeli, A., Tzanakis, N., Rallis, G., Kouraklis, G., Theocharis, S., 2009. Serum tissue inhibitor of metalloproteinase 1 and 2 (TIMP-1 and TIMP2) levels in colorectal cancer patients: associations with clinicopathological variables and patient survival. Int. J. Biol. Markers 24(4), 245-252. Available at: https://doi.org/10.1177/172460080902400405.

Graziano, F., Cascinu, S., 2003. Prognostic molecular markers for planning adjuvant chemotherapy trials in Dukes' B colorectal cancer patients: how much evidence is enough? Ann. Oncol. 14, 1026-1038. Available at: https://doi.org/10.1093/annonc/mdg284.

Hayakawa, T., Yamashita, K., Tanzawa, K., Uchijima, E., Iwata, K, 1998. Growth promoting activity of tissue inhibitor of metalloproteinases-1 (TIMP-1) for a wide range of cells. A possible new growth factor in serum. FEBS Lett. 298, 29-32. Available at: https://doi.org/10.1016/0014-5793(92)80015-9.

Lambert, E., Dasse, E., Haye, B., Petitfrere, E., 2004. TIMPs as multifacial proteins. Crit. Rev. Oncol. Hematol. 49, 187198. Available at: https://doi.org/10.1016/j.critrevonc.2003.09.008.

Leco, K.J., Khokha, R., Pavloff, N., Hawkes, S.P., Edwards, 
D.R., 1994. Tissue inhibitor of metalloproteinases-3 (TIMP-3) is an extracellular matrix-associated protein with a distinctive pattern of expression in mouse cells and tissues. J. Biol. Chem. 269, 9352-9360.

Lee, H.J., Choi, J.W., Kim, Y.S., 2011. Plasma or Serum TIMP1 is a Predictor of Survival Outcomes in Colorectal Cancer: a Meta-analysis. J. Gastrointestin. Liver Dis. 20(3), 287291.

Makitalo, L., 2010. Matrix Metalloproteinases and their Tissue Inhibitors as Biomarkers in Ulcerative Colitis and Crohn's Diseas [dissertation]. University of Helsinki, Helsinki, Finland. Available at: http://urn.fi/URN:ISBN:978-952-106406-7.

Nagase, H., Visse, R., Murphy, G., 2006. Structure and function of matrix metalloproteinases and TIMPs. Cardiovasc. Res. 69, 562-573. Available at: https://doi.org/10.1016/j.cardiores.2005.12.002.

Oberg, A., Höyhtyä, M., Tavelin, B., Stenling, R., Lindmark, G., 2000. Limited value of preoperative serum analyses of matrix metalloproteinases (MMP-2, MMP-9) and tissue inhibitors of matrix metalloproteinases (TIMP-1, TIMP-2) in colorectal cancer. Anticancer Res. 20(2B), 1085-1091.

Pellegrini, P., Contasta, I., Berghella, A.M., Gargano, E., Mammarella, C., Adorno, D., 2000. Simultaneous measurement of soluble carcinoembryonic antigen and the tissue inhibitor of metalloproteinase TIMP1 serum levels for use as markers of pre-invasive to invasive colorectal cancer. Cancer Immunol. Immunother. 49(7), 388-394. Available at: https://doi.org/10.1007/s002620000129.
Stetler-Stevenson, W.G., 2008. Tissue inhibitors of metalloproteinases in cell signaling: metalloproteinaseindependent biological activities. Sci. Signal. 1(27), re6. Available at: http://doi.org/10.1126/scisignal.127re6.

Stetler-Stevenson, W.G., Seo, D.W., 2005. TIMP-2: an endogenous inhibitor of angiogenesis. Trends Mol. Med. 11, 97-103. Available at: http://doi.org/10.1016/j.molmed.2005.01.007.

Stricklin, G.P., Li L., Jancic, V., Wenczak, B.A., Nanney, L.B., 1993. Localization of mRNAs representing collagenase and TIMP in sections of healing human burn wounds. Am. J. Pathol. 143, 1657-1666. Available at: https://www.ncbi.nlm.nih.gov/pubmed/8256854.

Visse, R., Nagase, H., 2003. Matrix metalloproteinases and tissue inhibitors of metalloproteinases: structure, function, and biochemistry. Circ. Res. 92, 827-839. Available at: https://doi.org/10.1161/01.RES.0000070112.80711.3D.

Welgus, H.G., Jeffrey, J.J., Eisen, A.Z., 1981. The collagen substrate specificity of human skin fibroblast collagenase. J. Biol. Chem. 256, 9511-9515. Available at: https://doi.org/10.1016/S0174-173X(85)80038-8.

Yamashita, K., Suzuki, M., Iwata, H., Koike, T., Hamaguchi, M., Shinagawa, A., Noguchi, T., Hayakawa, T., 1996. Tyrosine phosphorylation is crucial for growth signaling by tissue inhibitors of metalloproteinases (TIMP-1 and TIMP2). FEBS Lett. 396, 103-107. Available at: https://doi.org/10.1016/0014-5793(96)01066-6.

Zlobec, I., Lugli, A., 2008. Prognostic and predictive factors in colorectal cancer. Postgrad. Med. J. 84, 403-411. Available at: http://dx.doi.org/10.1136/jcp.2007.054858.

\title{
Прогностичко значење на ткивните инхибитори на матрикс металопротеинази ТИМП-1 и ТИМП-2 кај пациенти со колоректален карцином
}

\author{
Елена Костова ${ }^{1 *}$, Славица Шубеска Стратрова ${ }^{2}$ \\ ${ }^{1}$ Институт за претклиничка и клиничка фармакологија со токсикологија, \\ Медииински факултет, Универзитет „Св. Кирил и Методиј”, \\ 50 Дивизија 6, 1000 Скопје, Република Северна Македонија \\ ${ }^{2}$ Универзитетска клиника за ендокринологија, дијабетес и метаболички болести, \\ Медицински факултет, Универзитет „Св. Кирил и Методиј”, \\ Мајка Тереза 17, 1000 Скопје, Република Северна Македонија
}

Клучни зборови: колоректален карцином, ТИМП-1, ТИМП-2, прогноза

Целта на оваа студија беше да се анализираат серумските нивоа на ТИМП-1 и ТИМП-2 кај пацинети со колоректален карцином (КРК), да се корелираат резултатите со патолошкиот стадиум на болеста и со исходот, и притоа да се евалуира улогата на серумските нивоа на ТИМП-1 и ТИМП-2 како прогностички маркери.

Истражувањето беше направено на 82 пациенти со операбилен КРК без далечни метастази, од кои беа земени крвни примероци за одредување на серумските нивоа на ТИМП-1 и ТИМП-2 во следните временски точки: предоперативно, како и 3, 6, 9 и 12 месеци постоперативно. 
Беа најдени сигнификантни разлики помеѓу серумските нивоа на ТИМП-1 и ТИМП-2 предоперативно и постоперативно, исто така беше утврдена сигнификантна поврзаност на серумските нивоа на ТИМП-1 предоперативно кај пациентите со КРК во стадиум I и III, во 3-от и 6-от месец $(p<0,001)$ постоперативно. Серумските нивоа на ТИМП-2 добиени предоперативно беа сигнификантно поврзани со исходот на пациентите со КРК. Анализата на добиените ТИМП-1 и ТИМП-2 серумски нивоа кај пацинетите со КРК покажа статистички значајни разлики со прогресијата на болеста, со вредностите пред и после хемотерапиското лекување.

Од резултатите се сугерира заклучок дека серумските нивоа на ТИМП-1 и ТИМП-2 би можеле да служат како индикатори за појавата и прогресијата на КРК, а воедно може да бидат вредни и корисни маркери за следење на ефектите од хемотерапиското лекување. 